\title{
Implementasi Studi Karyawisata Mahasiswa PGSD dalam \\ Kajian Matakuliah IPS SD
}

\author{
Zuni Eka Tiyas Rifayanti \\ STKIP Bina Insan Mandiri \\ zunieka@stkipbim.ac.id
}

\begin{abstract}
Abstrak
Jenis penelitian yang akan digunakan adalah jenis Penelitian Tindakan Kelas (Classroom Action Research/CAR). Melalui penelitian ini penulis bertujuan untuk memberikan skill kepada mahasiswa PGSD STKIP Bina Insan Mandiri untuk dapat menjadi calon guru yang mampu bersaing serta professional dalam bidangnya.Hasil survey studi dokumentasi selama satu semester menunjukkan bahwa mahasiswa semester 5 PGSD STKIP Bina Insan Mandiri masih belum inovatif dalam mengikuti pembelajaran matakuliah IPS SD. Hal tersebut dikarenakan pemberian metode mengajar yang kurang inovatif dan cendenrung membosankan. Kemonotonan pembelajaran yang dilakukan dikelas menjadi salah satu faktornya
\end{abstract}

Kata Kunci: Studi Karyawisata, IPS SD, implementasi mahasiswa PGSD

\begin{abstract}
. The type of research to be used is Classroom Action Research (CAR). Through this study the authors are to provide skills to students PGSD STKIP Bina Insan Mandiri to be a prospective teacher who can compete as well as professionals in the field. The result of documentation study survey during one semester shows that 5th semester students of PGSD STKIP Bina Insan Mandiri are still not innovative in following IPS elementary course. This is because the provision of teaching methods that are less innovative and cendenrung boring. Monotonous learning done in the class become one of the factors.
\end{abstract}

Keywords: Study Tour, IPS SD, implementation of PGSD students 


\section{PENDAHULUAN}

Pada saat ini profesionalitas dari seorang dosen sangat dibutuhkan di setiap pembelajaran yang diberikan.Metode - metode pembelajaran yang konvensional sudah banyak ditinggalkan karena dianggap kurang memberikan perubahan yang memuaskan terhadap prestasi belajar mahasiswa.Disamping dianggap kurang dapat memberi perubahan terhadap prestasi belajar mahasiswa, anggaran pendidikan yang diberikan oleh pemerintah kepada bidang pendidikan, cukup besar.Pemerintah berani menganggarkan 20\% dari APBN untuk meningkatkan kualitas pendidikan di negara kita, untuk meningkatkan kualitas tenaga pendidik yakni dosen.Sehingga tidak ada alasan bagi para dosen untuk tidak belajar melakukan perubahan - perubahan yang lebih baik dalam meningkatkan mutu/ kualitas pengajarannya.

Pendidikan meupakan kegiatan yang sangat penting bagi penyiapan anak-anak untuk menghadapi kehidupannya di masa mendatang. Bahkan gejala proses pendidikan ini sudah ada sejak manusia ada, meskipun proses pelaksanaannya masih sangat sederhana. Namun hal ini merupakan fenomena bahwa proses pendidikan sejak dahulu kala sudah ada. Karena begitu sederhananya proses pendidikan pada jaman dahulu kala itu maka dirasa orang tidak menyadari bahwa apa yang dilakukan itu adalah proses pendidikan.

Proses pendidikan memang masalah universal, yang dialami oleh setiap bangsa atau suku bangsa. Oleh karena itu akan terpengaruh oleh berbagai fasilitas, budaya, situasi, serta kondisi bangsa atau suku bangsa tersebut. Dengan demikian akan terlihat adanya perbedaan-perbedaan yang dapat dilihat dalam pelaksanaan pendidikan tersebut. Namun yang jelas akan kita lihat adanya kesamaan tujuan yakni untuk mendewasakan anak dalam arti anak akan dapat berdiri sendiri di tengah masyarakat luas. Lebih-lebih bila dilihat di negara-negara yang sudah maju akan jauh berbeda pelaksanaannya dibanding dengan di negara-negara atau daerah-daerah yang belum maju.

Pengajaran IPS yang berkualitas adalah pengajaran IPS yang senantiasa menekankan aspek keterkaitan dari berbagai materi ilmu sosial dalam konteks kekinian dan sesuai dengan pengajaran di SD. Dalam sejarah pengajaran IPS (social studies) di Amerika Serikat, pengajaran IPS sebelum tahun 1960an, pada umumnya menekankan pada tujuan penguasaan materi atau hasil belajar dengan metode-metode mengajar yang berpusat pada guru (teacher centeral) seperti metode ceramah, penelaah buku ajar, dan sebagainya. Pendidikan IPS dalam menyelenggarakan pendidikan di Indonesia masih relatif baru digunakan. Pendidikan IPS merupakan padanan dari social studies dalam konteks kurikulum di Amerika Serikat. Istilah tersebut pertama kali digunakan di AS pada tahun 1913 mengadopsi nama lembaga Social Studies yang mengembangkan kurikulum di AS (Marsh dalam Etin,2007).

Pendidikan Ilmu Pengetahuan Sosial (IPS) di SD harus memperhatikan kebutuhan anak yang berusia antara 6-12 tahun. Anak dalam kelompok usia 7-11 tahun menurut Piaget (1963) berada dalam perkembangan kemampuan intelektual/kognitifnya pada tingkatan kongkrit operasional. Mereka memandang dunia dalam keseluruhan yang utuh, dan menganggap tahun yang akan datang sebagai waktu yang masih jauh. Yang mereka pedulikan adalah sekarang (=kongkrit), dan bukan masa depan yang belum bisa mereka 
pahami (=abstrak). Padahal bahan materi IPS penuh dengan pesan-pesan yang bersifat abstrak. Konsep-konsep seperti waktu, perubahan, kesinambungan (continuity), arah mata angin, lingkungan, ritual, akulturasi, kekuasaan, demokrasi, nilai, peranan, permintaan, atau kelangkaan adalah konsep-konsep abstrak yang dalam program studi IPS harus dibelajarkan kepada siswa SD.

Berbagai cara dan teknik pembelajaran dikaji untuk memungkinkan konsep-konsep abstrak itu dipahami anak. Bruner (1978) memberikan pemecahan berbentuk jembatan bailey untuk mengkongkritkan yang abstrak itu dengan enactive, iconic, dan symbolic melalui percontohan dengan gerak tubuh, gambar, bagan, peta, grafik, lambang, keterangan lanjut, atau elaborasi dalam kata-kata yang dapat dipahami siswa. Itulah sebabnya IPS SD bergerak dari yang kongkrit ke yang abstrak dengan mengikuti pola pendekatan lingkungan yang semakin meluas (expanding environment approach) dan pendekatan spiral dengan memulai dari yang mudah kepada yang sukar, dari yang sempit menjadi lebih luas, dari yang dekat ke yang jauh, dan seterusnya : dunia-negara tetangganegara-propinsi-kota/kabupaten-kecamatan-kelurahan/desa-RT/RW-tetangga-keluarga-

Aku.

Menurut Mulyasa (2005) Metode field trip atau karya wisata merupakan suatu perjalanan atau pesiar yangdilakukan oleh peserta didik untuk memperoleh pengalaman belajar, terutama pengalaman langsung dan merupakan bagian integral dari kurikulum sekolah. Meskipunkarya wisata memiliki banyak hal yang bersifat non akademis, tujuan umum pendidikan dapat segera dicapai, terutama berkaitan dengan pengembangan wawasan pengalamantentang dunia luar.

Dalam implementasi studi karyawisata mahasiswa PGSD STKIP Bina Insan Mandiri dalam kajian matakuliah Pendidikan IPS SD, yaitu dengan melaksanakan kunjungan keberbagai peninggalan sejarah diantaranya yang sudah mereka kunjungi yaitu : a) tugu pahlawan Surabaya serta museum 10 november, b) museum mputantular, c) berbagai peninggalan sejarah di Mojokerto candi tikus, candi bajangratu, candi Brahu, candi Gentong, patung budha tidur, dan museum trowulan. Dalam studikaryawisata disana mahasiswa melaksanakan observasi serta praktik mengajarkan materi sejarah dan peninggalan nya pada materi IPS SD. Dengan pelaksanaan seperti itu mahasiswa mampu mengembangkan pengetahuan yang didapat terhadap skill mengajar siswa SD yang mana disaat mereka manjadi guru SD adakalanya agenda studi karyawisata dilaksanakan di Sekolah tersebut. Dan dengan menadakan studi karyawisata maka mahasiswa sudah dibekali untuk membimbing siswa nya dalam melakukan studi karyawisata pada materi IPS.

Kegiatan ini dilakukan selama 9 SKS atau setara tiga kali tatap muka dengan durasi 360 menit.Studi karyawisata yang telah dilaksanakan. Luaran akhir dari implementasi matakuliah pendidikan IPS SD ini yaitu mahasiswa diharap mampu menguasai materi IPS SD serta pengaplikasian metode pembelajaran IPS SD dalam kegiatan proses belajar mengajar yang tidak harus dilaksanakan di dalam kelas.

Dari keinginan para dosen untuk merubah paradigma pembelajaran dari metode konvensional menuju ke pembelajaran yang inovatif, muncul beberapa model dan 
metode yang dianggap mampu memberikan inovasi - inovasi dalam pembelajaran.Salah satunya adalah pembelajaran melalui studi karyawisata.Dengan adanya implikasi pembelajaran IPS SD dengan studi karyawisata tentunya mampu memberikan nuansa pembelajaran yang menarik dan tidak membosankan sehingga dapat meningkatkan ketrampilan mengajar mahasiswa dalam mempraktikkan pengajaran IPS di Sekolah Dasar.

Tujuan penelitian ini adalah untuk mengetahui bagaimana penerapan pembelajaran studi karyawisata pada kajian matakuliah IPS PGSD Semester 5 STKIP Bina Insan Mandiri serta mengetahui aktivitas mahasiswa Semester 5 STKIP Bina Insan Mandiri dalam melaksanakan pembelajaran studi karyawisata pada kajian matakuliah IPS PGSD

\section{METODE PENELITIAN}

Jenis penelitian yang akan digunakan adalah jenis Penelitian Tindakan Kelas (Classroom Action Research/CAR). Penelitian Tindakan Kelas adalah suatu pencermatan terhadap kegiatan belajar, berupa sebuah tindakan yang sengaja dimunculkan dan terjadi dalam sebuah kelas secara bersama (Arikunto, 2006:8).

\section{SIKLUS PENELITIAN}

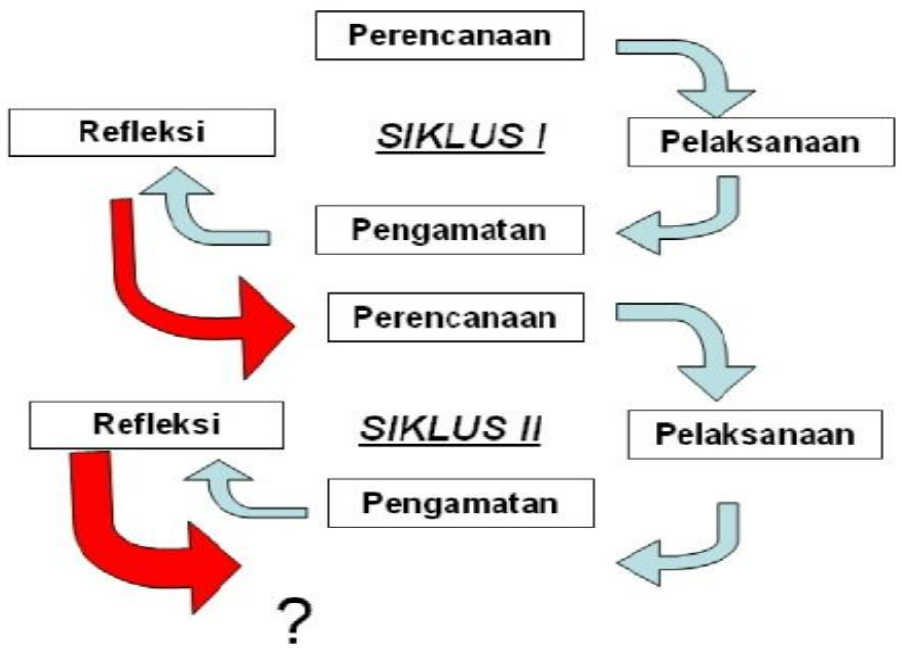

Gambar 1. Gambar siklus penelitian PTK

(Arikunto,dkk.2010 : 16)

Instrumen penelitian adalah alat bantu yang digunakan untuk memperoleh data dengan menggunakan metode tertentu. Dalam penilitian yang dirancang ini peneliti menggunakan dua metode untuk memperoleh data yang akan dijadikan informasi dalam penyelesaian penulisan ini, yaitu: Metode angket atau kuisioner dan Metode Observasi.

Kegiatan penelitian ini dilaksanakan di semester 5 Prodi PGSD STKIP Bina Insan Mandiri Jl.Raya menganti kramat No.133 Wiyung Surabaya dalam waktu satu semester, yaitu September - Januari 2017. Subyek penelitian ini adalah 25 Mahasiswa semester 
V Prodi PGSD STKIP Bina Insan Mandiri.Sumber data yang terkait dengan penelitian meliputi: (1) data aktivitas; (2) data dari informan atau subyek penelitian; (3) data dokumenter; dan (4) data lokasi penelitian. Setiap sumber data akan diambil dan diukur berbagai data seperti pada.

Penelitian ini menggunakan jenis penelitian tindakan kelas (PTK) yaitu penelitian yang dilakukan oleh dosen kelas atau di sekolah tempat mengajar, dengan penekanan pada penyempurnaan atau peningkatan praktik dan proses dalam pembelajaran (Susilo, 2007 : 16). PTK digambarkan dalam sebuah siklus yang melalui empat tahapan, yaitu perencanaan, tindakan, observasi, dan refleksi.

\section{Perencanaan}

Dalam tahap ini peneliti menentukan waktu pelaksanaan sehingga dapat dikonfirmasikan dengan dosen dan mahasiswa.Hal ini bertujuan agar pada saat pelaksanaan penelitian dosen sejawat juga dapat memberikan bimbingan dan arahan kepada peneliti mengenai hambatan-hambatan dalam pelaksanaan penelitian dan bisa saling membantu mengatasinya.

\section{Pelaksanaan Tindakan}

Penelitian tindakan adalah pelaksanaan yang merupakan implementasi atau penerapan isi rancangan yang tealh disusun sebelumnya.Adapun dalam tahap pelaksanaan tindakan ini terdapat dua tahap lagi, yaitu :

a. Tahap Persiapan

Dalam tahap persiapan ini peneliti telah menyiapkan rencana pelaksanaan pembelajaran atau RPP, lembar kegiatan mahasiswa, dan media pembelajarannya.Semua yang disebutkan ditampilkan sesuai dengan materi yang disajikan dapat menarik fakta berupa data yang dibutuhkan dalam penelitian ini.

b. Tahap Pelaksanaan

Pada tahap pelaksanaan peneliti mengadakan uji coba berupa penerapan metode pembelajaran langsung pada materi yang ditentukan yang dilaksanakan di dalam kelas.Selanjutnya peneliti melakukan tahapan yang telah ditentukan untuk melaksanakan penelitian.Di bagian akhir tahap ini, diadakan tes untuk mengukur sejauh mana tingkat pemahaman mahasiswa terhadap materi yang disajikan serta hasil pengamatan yang mana menilai kemampuan mahasiswa dalam menerapkan kajian matakuliah Pendidikan IPS SD pada kegiatan studi kayawisata.

\section{Pengamatan}

Kegiatan observasi ini dilakukan oleh pengamat dan dilaksanakan pada waktu penelitian berlangsung. Yang menjadi pengamat adalah rekan sejawat. Hal ini bertujuan agar peneliti mengetahui letak kekurangan dan kelebihan saat melakukan tindakan.

\section{Refleksi}

Kegiatan refleksi ini dilakukan untuk mengemukakan kembali apa yang sudah dilakukan. Kegiatan ini dilaksanakan ketika peneliti sudah selesai melakukan tindakan kemudian bersama para pengamat melakukan diskusi. Tujuan dari kegiatan refleksi ini adalah untuk mengetahui sejauh mana kesuksesan peneliti dalam 
tindakan. Disamping itu kegiatan refleksi inilah yang menjadi penentu apakah akan dilakukan siklus selanjutnya atau tidak, berdasarkan hasil penelitian yang diperoleh.

\section{Analisis Data}

Dalam menganalisis data, peneliti harus mampu menentukan metode analisis mana yang digunakan sesuai dengan jenis data-data dan rancangan penelitian yang digunakan. Berdasrkan sifat data yang dihimpun, yaitu data kuantitatif, maka untuk menganalisis data hasil observasi peneliti menggunakan teknik analisis data sebagai berikut :

$$
\mathrm{P}=\frac{f}{N} \times 100 \%
$$

Keterangan :

$\mathrm{P}$ : Prosentase yang sedang dicari

$\mathrm{f}$ : Jumlah skor jawaban yang diperoleh

$\mathrm{N}$ : Jumlah item dikali skor yang semestinya diperoleh

(Sudjiono, 1996:246)

Setelah itu dinyatakan dengan kriteria :

$76 \%-100 \%$ : Baik

$56 \%-75 \%$ : Cukup baik

$40 \%-55 \%$ : Kurang baik

$<40 \% \quad$ : Tidak baik

(Arikunto, 1998:246)

Kemudian untuk mengetahui ketuntasan belajar mahasiswa dalam tiap siklus, maka digunakan rumus:

$$
P=\frac{f_{1}}{n} \times 100 \%
$$

dan untuk mengetahui ketidaktuntasan belajar mahasiswa digunakan rumus:

$$
P=\frac{f_{2}}{n} \times 100 \%
$$

Keterangan:

$\mathrm{P}=$ prosentase

$\mathrm{f}_{1}=$ jumlah mahasiswa yang tuntas belajar

$\mathrm{f}_{2}=$ jumlah mahasiswa yang tidak tuntas belajar

$\mathrm{n}=$ jumlah mahasiswa

( Nana Sudjana 1996： ) 
Dalam menganalisis data yang dikumpulkan dengan metode tes, peneliti menggunakan rumus menurut Sukardi (2007:86), yaitu :

$$
\text { Mean }=\frac{Z x}{N}
$$

Keterangan :

$$
\begin{array}{ll}
\text { Mean } & \text { : Rata }- \text { rata } \\
\sum \mathrm{x} & \text { : Jumlah nilai mahasiswa dalam } 1 \text { kelompok } \\
\mathrm{N} & \text { : Jumlah seluruh mahasiswa }
\end{array}
$$

(Drs. Asep Jihad, M. Pd dan Drs. Abdul Haris, M. Sc, 2008:146)

1. Indikator Keberhasilan Belajar Mengajar

Keberhasilan dan kegagalan dalam belajar mengajar merupakan sebuah ukuran atas proses pembelajaran. Apabila merujuk pada rumusan operasional keberhasilan belajar, maka belajar dikatan berhasil apabila:

a. daya serap terhadap bahan pengajaran yang diajarkan mencapai prestasi, baik secara individu maupun kelompok.

b. perilaku yang digambarkan dalam indikator telah dicapai oleh mahasiswa baik secara individual maupun kelompok.

c. terjadinya proses pemahaman materi yang secara sekuensial mengantarkan materi tahap berikutnya.

(Pupuh Faturrohman, dkk, 2007:113)

Dalam penelitian ini, peneliti menentukan nilai standar keberhasilan belajar.Mahasiswa yang memperoleh nilai $\geq 60$ dinyatakan tuntas belajarnya (berhasil), sedangkan mahasiswa yang mendapatkan nilai < 60 dinyatakan tidak tuntas belajar (tidak berhasil).

\section{HASIL DAN PEMBAHASAN}

Dalam pelaksanaan penelitian tersebut dosen menggunakan penerapan Metode Pembelajaran Bermaian Peran.Penelitian ini dilakukan melalui 2 siklus. Adapun penjelasan untuk masing-masing siklus adalah sebagai berikut:

\section{PELAKSANAAN SIKLUS I}

a. Perencanaan

Melalui hasil pengamatan yang dilakukan, mahasiswa PGSD semester 5 STKIP Bina Insan Mandiri kadang-kadang sulit untuk menjelaskan suatu peristiwa sosial yang terjadi di masyarakat. Mahasiswa hanya sekedar tahu peristiwa sosial tersebut terjadi, tetapi mereka tidak tahu apa sebenarnya yang terjadi dalam peristiwa sosial itu. Salah satu contohnya adalah peninggalan sejarah dan cerita sejarah tempat tempat di Indonesia.Yang diketahui mahasiswa selama ini adalah kajian secara teoritis tanpa implikasi keberadaannya. Mereka tidak tahu apa itu sebenarnya peninggalan sejarah yang masih bisa digali dan dilihat keberadaannya melalui museum, bagaimana kegiatan sejarah itu terjadi. Berdasarkan hal tersebut, peneliti menggunakan metode pembelajaran studi karyawisata sebagai alternatif pemecahan masalah yang ada.Pada siklus I peneliti melaksanakan pembelajaran menggunakan metode pembelajaran 
langsung yang dilakukan didalam kelas.Sebelum pembelajaran dilaksanakan, peneliti melakukan persiapan yang menunjang pembelajaran, yaitu RPS, RPP, lembar kerja mahasiswa, lembar observasi, media pembelajaran, data angket mahasiswa.

b. Tindakan

Setelah melaksanakan persiapan, selanjutnya peneliti melaksanakan implikasi pembelajaran studikaryawisata dalam kajian matakuliah IPS SD. Pada siklus I ini peneliti tidak menggunakan metode studi karyawisata. Peneliti hanya menggunakan metode ceramah, tanya jawab, dan penugasan dan perkuliahan dilaksanakan didalam kelas dengan model pembelajaran langsung. Dalam pembelajaran, peneliti (yang bertindak sebagai dosen) menjelaskan materi dan mengajak mahasiswa untuk belajar aktif dengan mengadakan tanya jawab kepada mahasiswa dan memberikan kesempatan kepada mahasiswa untuk mengutarakan pendapatnya. Diakhir pembelajaran peneliti (yang bertindak sebagai dosen) bersama mahasiswa menyimpulkan materi dan dilanjutkan mengerjakan lembar kerja mahasiswa.

c. Observasi

Selama kegiatan pembelajaran berlangsung, peneliti melakukan pengamatan kepada mahasiswa, untuk mengetahui aktifitas mahasiswa selama pembelajaran. Peneliti menentukan beberapa kriteria yang diamati dan di bawah ini adalah data observasi yang diperoleh peneliti. Dalam pelaksanaan siklus I ini, pembelajaran berjalan lancar seperti biasa, meskipun ada beberapa mahasiswa yang sering mengganggu temannya ketika pembelajaran berlangsung. Yang jelas terlihat adalah antusisa mahasiswa dalam mengikuti perkuliahan cenderung membosankan diakibatkan kemonotonan dalam kegiatan belajar mengajar yang dilakukan didalam kelas.

d. Refleksi

Dari pelaksanaan pembelajaran dan hasil observasi yang dilakukan, ada beberapa hal yang perlu di benahi oleh peneliti untuk pembelajaran selanjutnya, yaitu pemberian penguatan kepada mahasiswa yang kurang memperhatikan pembelajaran agar tidak mengganggu mahasiswa yang lain. Selain itu, lebih diaktifkan kepada mahasiswa untuk bertanya kepada dosen apabila tidak mengerti tentang materi.

\section{PELAKSANAAN SIKLUS II}

a. Perencanaan

Sebagai tindak lanjut dari pembelajaran sebelumnya, peneliti melakukan siklus II dengan menerapkan metode studi karyawisata dalam implementasi kajian matakuliah IPS SD. Sebelum melaksanakan pembelajaran, peneliti menyiapkan RPS, RPP, lembar kerja mahasiswa, lembar observasi, lembar angket, serta bahan dan alat yang digunakan untuk studi karyawisata

b. Tindakan

Setelah mengadakan persiapan, peneliti melaksanakan pembelajaran implementasi studi karyawisata pada kajian matakuliah IPS SD mahasiswa PGSD STKIP Bina Insan Mandiri. Pada siklus II ini, peneliti menerapkan pembelajaran dengan menggunakan implementasi studi karyawisata. Sebelum memulai pelajaran, peneliti terlebih dahulu memperkenalkan kepada mahasiswa tentang metode studi karyawisata. Kemudian peneliti menawarkan kepada mahasiswa untuk menentukan lokasi tujuan studi karya wisata sesuai dengan bahan kajian yang akan di tempuh. Selanjutnya, peneliti memulai pembelajaran dengan tujuan yang sudah ditentukan, mahasiswa melakukan kegiatan studi karyawisata dengan materi IPS SD dalam kajian matakuliah yang sudah ditetapkan. Diakhir pembelajaran, mahasiswa 
membuat laporan hasil studi karyawisata yang sudah dilakukan. Pada kegiatan setelah studi karyawisata sudah dilaksanakan, peneliti memberikan LKS untuk mengetahui tingkat pemahaman mahasiswa terhadap materi yang disampaikan dilanjutkan dengan pengisian angket untuk mengetahui tanggapan balik dari mahasiswa.

c. Observasi

Proses pembelajaran pada siklus II berjalan dengan baik. Mahasiswa PGSD Semester 5 STKIP Bina Insan Mandiri sangat antusias sekali saat mengikuti pembelajaran dengan studi karyawisata. Kondisi ini berbeda dengan pembelajaran pada siklus I. Diawal pembelajaran saat peneliti ( sebagai dosen ). Berdasarkan hasil angket yang telah diberikan, sebagian besar mahasiswa menyukai pembelajaran dengan menggunakan studi karyawisata. Adapun beberpa alasan mengapa mahasiswa menyukai pembelajaran dengan bermain peran :

1) Lebih bersemangat belajar.

2) Suasana tidak membosankan karena dilakukan diluar kelas.

3) Aktif dalam pembelajaran.

Berikut ini adalah hasil observasi peneliti yang ditampilkan dalam bentuk tabel 1 dan tabel 2.

d. Refleksi

Berdasarkan hasil observasi yang dilakukan peneliti, pada siklus II ini kegiatan pembelajaran berjalan dengan baik. Dalam hasil tes terdapat peningkatan nilai dari beberapa mahasiswa. Penggunaan metode ini hanya memerlukan pembiasaan dalam kegiatan belajar sehari-hari agar mahasiswa mendapatkan variasi dalam kegiatan dalam pelaksanaan perkuliahan.

Tabel 1. Hasil observasi siklus II

\begin{tabular}{|c|l|c|c|c|}
\hline & \multicolumn{1}{|c|}{ Bahan observasi } & \multicolumn{3}{c|}{ Keterangan } \\
\cline { 3 - 5 } No. & \multicolumn{1}{|c|}{ B } & \multicolumn{1}{|c|}{ C } & K \\
\hline 1. & $\begin{array}{l}\text { Mahasiswa mendengarkan/memperhatikan penjelasan dosen } \\
\text { selama KBM }\end{array}$ & $\sqrt{ }$ & \\
2. & $\begin{array}{l}\text { Keaktifan mahasiswa dalam mengajukan pertanyaan } \\
3\end{array}$ & $\begin{array}{l}\text { Kemampuan mahasiswa untuk menyampaikan tanggapan } \\
\text { Kemempuan mahasiswa membuat kesimpulan tentang materi } \\
\text { pembelajaran. }\end{array}$ & $\sqrt{ }$ & \\
& & & & \\
\end{tabular}

Tabel 2 . Hasil observasi ketika implementasi studi karyawisata

\begin{tabular}{|l|l|c|c|c|}
\hline \multirow{2}{*}{ No. } & \multicolumn{1}{|c|}{ Bahan observasi } & \multicolumn{3}{c|}{ Keterangan } \\
\cline { 3 - 5 } & \multicolumn{1}{|c|}{ B } & C & K \\
\hline 1. & Pengalaman yang diterima mahasiswa dalam studi karyawisata & $\sqrt{ }$ & & \\
2. & Keaktifan mahasiswa dalam keikutsertaan studi karyawisata & & $\sqrt{ }$ & \\
3. & Kelengkapan data hasil studi karyawisata & $\sqrt{ }$ & & \\
4. & Kemempuan mahasiswa menjawab pertanyaan dengan benar & & $\sqrt{ }$ & \\
5. & Perhatian mahasiswa terhadap kegiatan belajar & $\sqrt{ }$ & & \\
\hline
\end{tabular}




\section{Metode Angket}

Angket ini digunakan untuk mengetahui tanggapan mahasiswa tentang pembelajaran yang telah dilakukan. Dari data angket yang diperoleh, peneliti mendapatkan beberapa informasi diantaranya adalah:

a. Mahasiswa senang dengan pembelajaran menggunakan implementasi studi karyawisata .

b. Mahasiswa menjadi aktif dalam memberikan tanggapan.

c. Mahasiswa lebih bersemangat belajar.

d. Mahasiswa mempunyai pengalaman praktik mengajar dengan implementasi pembelajaran IPS SD yang dilakukan melalui studi karyawisata.

\section{Metode Observasi}

Dari hasil penelitian dapat diketahui bahwa sebelum menggunakan studi karyawisata prosentasenya adalah 53,3\%, sedangkan setelah menggunakan implementasi studi karyawisata diperoleh prosentase sebesar $85 \%$. Maka dengan hasil tersebut di atas menunjukkan bahwa hasil observasi terhadap implementasi studi karyawisata termasuk dalam kategori baik karena terletak pada rentangan 76\%-100\%. Hal ini menunjukkan studi karyawisata dapat meningkatkan hasil belajar mahasiswa dan dapat digunakan sebagai salah satu metode mengajar matakuliah IPS. SD pada mahasiswa semester 5 PGSD STKIP Bina Insan Mandiri.

\section{KESIMPULAN DAN SARAN}

Implementasi studi karyawisata pada matakuliah IPS SD merupakan salah satu metode pembelajaran yang dapat menarik perhatian siswa dalam proses belajar mengajar pada mata kuliah IPS SD, sehingga mahasiswa mudah paham terhadap materi dan hasil belajar mahasiswa menjadi lebih baik

Berdasarkan hasil tes yang dilakukan dalam penelitian, terdapat peningkatan nilai rata-rata kelas dari siklus I yaitu sebesar 59,3 menuju siklus II dengan rata-rata 69,8. Hal ini menunjukkan bahwa hasil belajar dan pemahaman siswa terhadap matakuliah IPS SD motivasi belajar meningkat setelah penggunaan metode bermain peran. Adapun beberapa saran yang diberikan penulis berkaitan dengan hasil penelitian, yaitu

1. Dalam pembelajaran dikelas perlu dikenalkan metode-metode atau model pembelajaran yang baru agar suasana pemebelajaran di kelas tidak monoton dan membosankan.

2. untuk peneliti lanjutan terutama bagi para pendidik, jika akan meneliti tentang penelitian yang sama Memperhatikan waktu dan biaya pelaksanaan karena penerapan studi karyawisata membutuhkan waktu dan dana yang banyak. 


\section{DAFTAR PUSTAKA}

Fraenkel, Jack R. (1980). Helping students think value strategies for teaching social studies. New Jersey: Prentice-Hall.

Hunt, E. F., \& Colander, D. C. (1987). Social science. New York: Macmillan.

Jarolimek, J. (1967). Social studies in elementary education. New York: Macmillan.

Kenworthy, Leonard S (1981).Social studies for the eighties. Canada: John Wiley \& Sons.

Maxim, G. W. (1987). Social studies and the elementary school child ( $3^{\text {rd }}$ edition). USA: Merill.

Nana Sudjana. (2005). Dasar-dasar proses belajar mengajar. Bandung: Sinar Baru Algesindo.

Numan Somantri. (2001). Menggagas pembaharuan pendidikan IPS. Bandung: Remaja Rosdakarya.

Tilstone, C. (Ed). (1998). Observing, teaching, and learning: principles and practice. London: David Fulton. 